\title{
Intra-EU Investment Arbitration after the Achmea Case: Legal Autonomy Bounded by Mutual Trust? ${ }^{\dagger}$
}

\author{
ECJ 6 March 2018, Case C-284/16, Slovak Republic v Achmea
}

Jens Hillebrand Pohl*

\section{INTRODUCTION}

In its much-awaited preliminary ruling in the Achmea case delivered on 6 March $2018,{ }^{1}$ the European Court of Justice considered that investor-State dispute settlement (ISDS) under a bilateral investment treaty (BIT) between two Member States could adversely affect the autonomy of the EU legal order, because EU law matters could be decided without the Court as final arbiter. Adding to a long line of cases defending EU legal autonomy, ${ }^{2}$ the Court ruled that if an arbitral tribunal is called upon to resolve a dispute liable to relate to the interpretation or application of EU law, the tribunal's decisions must be subject to mechanisms capable of ensuring the full effectiveness of EU law. For this purpose, either the tribunal must be situated within the judicial system of the EU, or its rulings must be subject to review by a court or tribunal of a Member State so situated, such that, in either case, questions of EU law can ultimately be submitted to the Court by means of a reference for a preliminary ruling. Since these conditions were not

*Visiting Research Fellow, T.M.C. Asser Institute; Doctoral Candidate, Department of International and European Law, Maastricht University.

${ }^{1}$ ECJ 20 April 2018, Case C-284/16, Slovak Republic v Achmea, EU:C:2018:158.

${ }^{2}$ See Opinion 2/13 (Accession of the EU to the ECHR), EU:C:2014:2454; Opinion 1/09 (Unified patent litigation system), EU:C:2011:123; ECJ 30 May 2006, Case C-459/03, Commission v Ireland (MOX Plant), EU:C:2006:345; Opinion 1/00 (European Common Aviation Area), EU:C:2002:231; Opinion 2/94 (Accession of the EC to the ECHR), EU:C:1996:140; Opinion 1/92 (Renegotiated European Economic Area), EU:C:1992:189; Opinion 1/91 (European Economic Area), EU: C:1991:490; Opinion 1/76 (European Laying-up Fund for Inland Waterway Vessels), EU:C:1977:63.

$\dagger$ This article has been updated since original publication. A notice detailing the changes has also been published at doi:https://doi.org/10.1017/S1574019618000482

European Constitutional Law Review, 14: 767-791, 2018

(C) 2018 The Authors. This is an Open Access article, distributed under the terms of the Creative Commons Attribution licence (http://creativecommons.org/licenses/by/4.0/), which permits unrestricted re-use, distribution, and reproduction in any medium, provided the original work is properly cited. doi:10.1017/S1574019618000366 
present with respect to the ISDS provision at issue - as is typical - the Court ruled that the ISDS provision was incompatible with EU law.

The subject matter of this ruling may seem technical, but the implications of the ruling are far-reaching. ISDS is the principal mechanism by which international investment law is enforced, ${ }^{3}$ enabling investors of one State to bring arbitration proceedings under international law against another State in which it has made an investment. ISDS is a typical element of BITs and also frequently of free trade agreements and other treaties with investment provisions, of which there are globally more than 3,000 signed and more than 2,500 currently in force among more than 200 States and territories. ${ }^{4}$ The EU and its Member States are parties to a majority (more than 1,500 ) of these treaties, ${ }^{5}$ including, controversially, slightly less than 200 treaties between Member States (intra-EU BITs). ${ }^{6}$

\footnotetext{
${ }^{3}$ To a lesser extent, international investment law is also enforced bilaterally, either between the investor's home State and the host State, through diplomatic protection or treaty-based inter-State arbitration, or between an investor and the host State directly, on a contractual basis (investment contracts) or on the basis of the host State's domestic investment laws. See e.g. P. Muchlinsky, 'Diplomatic Protection of Foreign Investors: a Tale of Judicial Caution', in C. Binder et al. (eds), International Investment Law for the $21^{\text {st }}$ Century: Essays in Honour of Christoph Schreuer (Oxford University Press 2009); A. Roberts, 'State-to-State Investment Treaty Arbitration: A Hybrid Theory of Interdependent Rights and Share Interpretive Authority', 55 Harvard International Law Journal (2014) p 1; A. von Walter, 'Investor-State Contracts in the Context of International Investment Law', in M. Bungenberg et al. (eds.), International Investment Law (Hart 2015); M. Burgstaller and M. Waibel, 'Investment Codes', in R. Wolfrum (ed.), Max Planck Encyclopedia of Public International Law (Oxford University Press 2012).

${ }^{4}$ United Nations Conference on Trade and Development (UNCTAD), Investment Policy Hub database, available at <investmentpolicyhub.unctad.org >, visited 27 October 2018.

${ }^{5} \mathrm{Ibid}$. Indeed, the very concepts of BIT and ISDS are in a historical perspective European legal innovations, pioneered by Germany in 1959 and Italy in 1969, respectively, which over the following decades became truly global standards. See A. Newcombe and L. Paradell, Law and Practice of Investment Treaties: Standards of Treatment (Kluwer Law International 2009) p. 42 at p. 45.

${ }^{6}$ There are currently 194 intra-EU BITs in force (and one - Italy-Malta BIT of 2002 - that has not entered into force), all of which were entered into prior to the EU accession of one of the parties, according to UNCTAD, Investment Policy Hub database, supra n. 4. All but two of these BITs (Germany-Greece BIT of 1961 and Germany-Portugal BIT of 1980) involve a 'new' Member State (i.e. one that acceded in 2004 or later) as one of the parties. However, not all those BITs have been concluded between 'new' and 'old' Member States. In fact, while 138 of the intra-EU BITs are indeed between a 'new' and an 'old' Member State, fully 54 of them are between two 'new' Member States $(i d$.$) . In addition, all Member States, except Italy, are, together with the EU itself, contracting$ parties to the Energy Charter Treaty, signed on 17 December 1994, 2080 UNTS 95, which contains multilateral investment treaty provisions. Italy was an original signatory of, and ratified, the Energy Charter Treaty, but notified its withdrawal from treaty in 2014 with effect from 1 January 2016. Like the Netherlands-Slovakia BIT, the Energy Charter Treaty and the other intra-EU BITs provide, with few exceptions, for ISDS and include ISDS clauses similar to that in the BIT at issue (ibid).
} 
This note provides an overview of the background to the Achmea case and a summary of the judgment itself, before offering some critical reflections on the Court's reasoning and on the legal and practical implications of its ruling.

\section{BACKGROUND TO THE CASE}

In 2004, Slovakia liberalised its sickness insurance market. Dutch insurer Achmea BV (formerly Eureko BV) entered that market and began offering private sickness insurance through a local subsidiary. Two years later, the Slovak government partially reversed its market liberalisation, in particular by prohibiting the distribution of profits generated from private sickness insurance activities. ${ }^{7}$

Achmea considered that this legislative reversal had caused it damage and had contravened Slovakia's undertakings under the BIT in force between Slovakia and the Netherlands. ${ }^{8}$ On the basis of the ISDS provision of the BIT, Achmea brought arbitration proceedings in 2008 against Slovakia. ${ }^{9}$ The arbitral tribunal, applying the United Nations Commission on International Trade Law (UNCITRAL) arbitration rules, chose Frankfurt am Main, Germany, as seat of arbitration, with the effect that German law governed the arbitration proceedings.

In the arbitral proceedings, Slovakia challenged the jurisdiction of the tribunal, arguing that, as a result of its accession to the European Union, recourse to the ISDS provision was incompatible with EU law. In this argument, Slovakia was supported by the European Commission, which has long maintained that all intraEU BITs should be terminated. It has argued that the matters regulated by these BITs fall under Union competences, ${ }^{10}$ that they discriminate between investors of

${ }^{7}$ The prohibition was subsequently lifted by a new law in 2011, after having been declared unconstitutional by the Slovak Constitutional Court.

${ }^{8}$ Agreement on Encouragement and Reciprocal Protection of Investments between the Kingdom of the Netherlands and the Czech and Slovak Federative Republic, signed on 29 April 1991, 2242 UNTS 224. This BIT was succeeded to by Slovakia upon the dissolution of Czechoslovakia in 1992, well before it joined the EU in 2004. According to the BIT, each contracting State undertook to ensure fair and equitable treatment, not to impair the operation, management, maintenance, use, enjoyment or disposal of investments by unreasonable or discriminatory measures, and to guarantee the free transfer of profits and other payments relating to investments. See Arts. 3(1) and 4.

${ }^{9}$ Ibid., Art. 8.

${ }^{10}$ The Commission has essentially alleged that there is an incompatibility between EU law and BITs being earlier treaties within the meaning of Art. 351 TFEU ( $c f$ Art. 59 of the Vienna Convention on the Law of Treaties), that EU law enjoys primacy, which enables it to prevail over treaties concluded between Member States and that there is equivalent investment protection under EU law. These arguments were dismissed by the arbitral tribunal in PCA Case No. 2008-13, Award on Jurisdiction, Arbitrability and Suspension dated 26 October 2010, Achmea (formerly Eureko) v Slovak Republic (I), paras. 175-203, 217-292; see also UNCITRAL Case No. 088/2004, Partial Award dated 27 March 2007, Eastern Sugar v Czech Republic, paras. 159-166; ICSID Case No. 
different Member States on the basis of their nationality, ${ }^{11}$ that enforcement of arbitral awards rendered under these BITs might violate State aid rules, ${ }^{12}$ and that arbitral tribunals might interpret and apply EU law without recourse to judicial review by the Court of Justice of the EU. ${ }^{13}$ Nonetheless, only 19 intra-EU BITs, i.e. less than $10 \%$ of the original number, have been terminated. ${ }^{14}$

The tribunal dismissed Slovakia's jurisdictional objection by an interlocutory award in $2010,{ }^{15}$ which Slovakia unsuccessfully sought to have set aside before German courts. In 2012, by its final award on the merits, the tribunal ordered Slovakia to compensate Achmea in the amount of $€ 22.1$ million. ${ }^{16}$

Turning again to German courts, Slovakia in 2013 brought an action to set aside the final arbitral award on the basis that the recognition or enforcement of the award would be contrary to public policy (ordre public). Unsuccessful at first instance in 2014, it then sought judicial review on a point of law from the Federal Court of Justice (Bundesgerichtshof), Germany's highest court of ordinary jurisdiction, in 2015. In those proceedings, Slovakia argued that the ISDS clause was incompatible with Article 18(1) TFEU (which prohibits discrimination on grounds of nationality), Article 267 TFEU (which provides for preliminary rulings by the Court of Justice of the $\mathrm{EU}$ on questions concerning the interpretation of EU law to be referred to it by 'courts and tribunals' in the Member States) and Article 344 TFEU (which prohibits Member States from

ARB/07/19, Decision on Jurisdiction, Applicable Law and Liability dated 30 November 2012, Electrabel v The Republic of Hungary, para. 4.147; SCC Arbitration No. V 062/2012, Final Award dated 21 January 2016, Charanne BV v Kingdom of Spain, paras. 424-450; SCC Case V2013/153, Award dated 12 July 2016, Isolux Infrastructure Netherlands BVv Kingdom of Spain, paras. 622-660. See also ICSID Case No. ARB/14/1, Award dated 16 May 2018, Masdar Solar \& Wind Cooperatief U.A. v Kingdom of Spain, paras. 306-324, 327-342.

${ }^{11}$ See e.g. European Commission, 'Commission asks Member States to terminate their intra-EU bilateral investment treaties', press release dated 18 June 2015; also Opinion of AG Wathelet, ECJ 19 September 2017, Case C-284/16, Slovak Republic v Achmea, ECLI:EU:C:2017:699, paras. 54-83.

${ }^{12}$ See e.g. Ioan Micula and others v Romania, ICSID Case No. ARB/05/20, Award dated 11 December 2013, 96.

${ }^{13}$ See e.g. Achmea v Slovakia, Award on Jurisdiction, Arbitrability and Suspension, supra n. 10, paras. 178, 276. However, 'old' Member States in particular have not shared the Commission's concerns and have in spite of the Commissions efforts 'preferred to maintain the existing arrangements', see Council of the European Union, Economic and Financial Committee (2008) Annual EFC Report on the Movement of Capital and the Freedom of Payments (ECFIN/CEFCPE (2008)REP/55806).

${ }^{14}$ UNCTAD, Investment Policy Hub database, supra n. 4. Interestingly, the 'new' Member States, including Slovakia, have been just as reluctant as the 'old' Member States in terminating the BITs, whether unilaterally or by mutual agreement. The possible reason for this was addressed in the AG's Opinion, supra n. 11, para. 38.

${ }^{15}$ Achmea v Slovakia, Award on Jurisdiction, Arbitrability and Suspension, supra n. 10.

${ }^{16}$ Ibid. 
submitting a dispute concerning the interpretation or application of EU law to any method of settlement other than those provided for in the EU Treaties).

To address these arguments and be able to decide the case before it, the Bundesgerichtshof stayed the proceedings and referred three questions to the European Court of Justice for a preliminary ruling. These were essentially the following:

(1) Does Article 344 TFEU preclude the application of an ISDS provision in a pre-accession intra-EU BIT, where the arbitral proceedings were not brought until after accession?

(2) If not, does Article 267 TFEU preclude the application of such ISDS provision?

(3) If not, does Article 18(1) TFEU preclude the application of such ISDS provision?

\section{The decision of the Court of Justice}

The Grand Chamber of the European Court of Justice delivered its ruling on 6 March 2018 - a brief judgment, given the complexity and importance of the matters involved - without specifically addressing the arguments put forward by the referring court in its request for a preliminary ruling. Nor did the Court even discuss the conclusions of Advocate General Wathelet, set forth in his 38-page Opinion delivered on 19 September 2017. ${ }^{17}$ Nonetheless, both the referring court's and the Advocate General's reasoning merit consideration, both as context and contrast to the Court's judgment, to get a full picture of the actual complexity of the case and of the arguments of the Bundesgerichtshof in the preliminary reference and the Advocate General's conclusions, which the Court implicitly dismissed.

\section{The referring court's request}

The Bundesgerichtshof was inclined to answer all three referred questions in the negative. With respect to the first question, the court considered that Article 344 TFEU was not even applicable to the settlement of disputes between an individual and a Member State. ${ }^{18}$ Moreover, it argued that the dispute at issue did not relate to the 'interpretation and application of the Treaties', but rather concerned the interpretation and application of the BIT. ${ }^{19}$ It was of the opinion that Article 344

\footnotetext{
${ }^{17}$ AG's Opinion, supra n. 11.

${ }^{18}$ Judgment, supra n. 1, para. 15.

${ }^{19}$ Ibid., para. 16.
} 
TFEU does not protect the exclusive jurisdiction of the EU judicature with respect to a judicial procedure that cannot be brought before it, since it is not possible for an investor to bring an investment treaty claim against a Member State before the courts of the Union. ${ }^{20}$

With respect to the second question, the referring court argued that, although the arbitral tribunal could not be regarded as a 'court or tribunal' within the meaning of Article 267 TFEU, the uniform application of EU law could nonetheless be safeguarded by the power of domestic courts of a Member State to review arbitral awards. ${ }^{21}$ Moreover, the referring court recalled that a special court or tribunal established by international agreement outside the EU judicial framework is compatible with EU law insofar as there is no adverse effect on the autonomy of the EU legal order, which might be ensured either by relying on the review of arbitral awards by domestic courts or by permitting tribunals to make references for preliminary rulings directly to the Court. ${ }^{22}$

Finally, with respect to the third question, the court noted that investors from Member States other than the Netherlands and Slovakia could not benefit from the ISDS provisions of the BIT in question and were consequently at a disadvantage compared to Dutch and Slovak investors in that respect. Nonetheless, the court argued that this disadvantage arose because the BIT was inherently bilateral in nature, only giving rise to rights and obligations with respect to nationals of the contracting Member States. As such, the investors of the other Member States were not in an objectively comparable situation to Dutch and Slovak investors and were therefore not discriminated against on the basis of their nationality, within the meaning of Article 18(1) TFEU. ${ }^{23}$

\section{The Advocate General's opinion}

The Advocate General also answered all the referred questions in the negative, concluding, first, that investor-State disputes did not come under Article 344 TFEU, ${ }^{24}$ that the dispute did not concern the interpretation or application of the TEU or TFEU, ${ }^{25}$ and that the ISDS clause did not undermine the allocation of powers fixed by these Treaties, because of national courts' jurisdiction to review arbitral awards through proceedings for the setting aside (annulment) of an award or for its recognition or enforcement. ${ }^{26}$

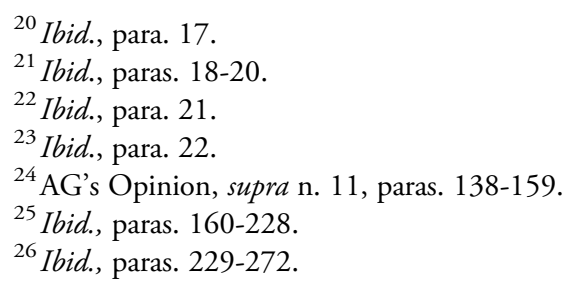


Second, the Advocate General concluded that the arbitral tribunal did indeed satisfy the criteria for a 'court or tribunal' for purposes of Article 267 TFEU, because it was established by law, it was permanent, its jurisdiction was compulsory, its procedure was inter partes, it applied rules of law in the settlement of the dispute before it, and its arbitrators were independent and impartial - all in the opinion of the Advocate General. ${ }^{27}$

Third, the Advocate General believed that the benefit of the ISDS clause conferred on Dutch investors did not amount to prohibited discrimination on grounds of nationality. He argued that Article 18 TFEU requires that persons in a situation governed by EU law be placed on a completely equal footing with nationals of the relevant Member State, but that there is no discrimination where a Member State does not afford the nationals of another Member State the treatment which it affords, by convention, to the nationals of a third Member State. Non-Dutch investors were thus not in the same situation as Dutch investors when investing in Slovakia, due to the inherently bilateral nature of BITs and that the benefit of the ISDS clause was not separable from the remainder of the BIT. ${ }^{28}$

\section{The judgment of the Court}

With the wealth of arguments before it - not only those put forward by the referring court and the Advocate General and the parties to the main proceedings, but also the various arguments of the 15 Member States that intervened in the case and of the Commission - the Court began by identifying the governing principles and their policy justifications, in light of which the questions referred for a preliminary ruling were to be answered. ${ }^{29}$ Paramount among those, was the principle of the autonomy of the EU legal system, enshrined in particular in Article 344 TFEU. ${ }^{30}$ This principle is "justified by the essential characteristics of the EU and its law, relating in particular to the constitutional structure of the EU and the very nature of that law', namely the fact that EU law stems from an independent source of law, has primacy over the laws of the Member States and may have direct effect. Those characteristics, the Court explained, have given rise to a 'structured network of principles, rules and mutually interdependent legal relations binding the EU and its Member States reciprocally and binding its Member States to each other'. ${ }^{31}$

Importantly, this justification, the Court went on to restate, results from the 'fundamental premiss' that the Member States mutually share, and recognise that

${ }^{27}$ Ibid., paras. 84-131.

${ }^{28}$ Ibid., paras. 49-83.

${ }^{29}$ Judgment, supra n. 1, paras. 32-37.

${ }^{30}$ Ibid., para. 32.

${ }^{31}$ Ibid., para. 33. 
they share, the common values stated in Article $2 \mathrm{TEU},{ }^{32}$ which in turn 'implies and justifies' the mutual trust among Member States that they will recognise those values and respect the EU law that implements them, inter alia in the context of the principle of sincere cooperation. ${ }^{33}$

Having thus affirmed the hierarchical lineage between: (1) the principle of the autonomy of the EU law; (2) the fundamental premise of shared common values; and (3) the underlying notion of mutual trust, the Court turned to the role of the EU judicial system, the purpose of which, it noted, is to preserve the specific characteristics and autonomy of the EU legal order. ${ }^{34}$ That role is essentially shared, pursuant to Article 19 TEU, between the Court of Justice, on the one hand, and the courts and tribunals of the Member States, on the other. ${ }^{35}$ All these courts constitute a system and are joined in a judicial dialogue by means of the preliminary ruling procedure established by Article 267 TFEU. ${ }^{36}$

On the basis of these considerations, the Court set forth to determine whether an ISDS provision such as that of the BIT at issue was compatible with Articles 267 and 344 TFEU.

First, the Court asked whether the disputes that might be brought to investorState arbitration under the BIT were liable to relate to the interpretation or application of EU law. ${ }^{37}$ The Court concluded that a tribunal under the BIT at issue might have to interpret and apply EU law 'particularly the provisions concerning the fundamental freedoms, including freedom of establishment and free movement of capital'. This was because the tribunal was called upon to decide the case taking into account in particular of the law in force of the contracting party concerned' [i.e. Slovak law] and 'other relevant agreements between the contracting parties' [i.e. the TEU and the TFEU], and because EU law both forms part of Slovak law and derives from international agreements. ${ }^{38}$ The disputes brought before the Achmea tribunal were therefore liable to relate to the interpretation and application of EU law, notably including matters concerning the fundamental freedoms.

\footnotetext{
${ }^{32}$ Ibid., para. 34 [emphasis added].

${ }^{33}$ Ibid.

${ }^{34}$ Ibid., para. 35.

${ }^{35}$ Ibid., para. 36.

${ }^{36}$ Ibid., para. 37; see also Opinion 2/13, supra n. 2, paras. 176, 198.

${ }^{37}$ Judgment, supra n. 1, paras. 39-42.

${ }^{38}$ Ibid., para. 41. Irrespective of the law applicable to the merits of the case, EU law was also part of the law governing the arbitration proceedings, i.e. German law as lex loci arbitri. Therefore, the tribunal would have had to interpret and apply EU law regardless of the substantive applicable law, e.g. in respect of the jurisdictional question of whether the dispute was non-arbitrable for reasons of EU public policy. CfAG's Opinion, supra n. 11, para. 176.
} 
Second, the Court proceeded to examine whether the Achmea tribunal was 'situated within the judicial system of the EU' and whether it thus was a 'court or tribunal of a Member State within the meaning of Article 267 TFEU' allowed to make a reference to the Court for a preliminary ruling. ${ }^{39}$ Rather than discussing the factors that have developed in case law for a judicial body to be considered a 'court or tribunal', ${ }^{40}$ the Court focused on the overarching requirement that the body in question must be 'situated within the judicial system of the EU'. The Court concluded that the tribunal did not form part of the Dutch or Slovak domestic judicial systems. ${ }^{41}$ Rather, the rationale of ISDS was to establish an adjudicatory remedy outside the judicial systems of the contracting parties to the BIT. ${ }^{42}$ For that reason, the tribunal could not be considered a 'court or tribunal of a Member State' for purposes of Article 267 TFEU, even if it otherwise were to satisfy the criteria for a 'court or tribunal' developed in case law. In addition, the Court clarified that a court common to several Member States could be situated within the judicial system of the EU, but that the Achmea tribunal lacked requisite links to either the Dutch or the Slovak judicial system and was thus not a 'court or tribunal' common to the Netherlands and Slovakia. ${ }^{43}$ The tribunal was therefore not entitled to make references to the Court for preliminary rulings and was not situated within the EU judicial system.

Third, the Court finally asked whether the Achmea award was subject to review by a court or tribunal of a Member State, which in turn could make a reference to the Court for a preliminary ruling and thus ensure the uniform interpretation and application, and full effectiveness, of EU law. While this was certainly so in this case (or else the case would not have reached the Court), it just happened to be the result of the tribunal having chosen Frankfurt am Main as its seat, which brought the proceedings under German law. ${ }^{44}$ The Court noted, however, that the judicial review of an award by court of a Member State may be limited by national law. ${ }^{45}$

\footnotetext{
${ }^{39}$ Judgment, supra n. 1, paras. 43-49.

${ }^{40}$ These factors include whether the body is established by law, whether it is permanent, whether its jurisdiction is compulsory, whether its procedure is inter partes, whether it applies rules of law, whether it is independent and whether a case is pending before it and it must be called upon to give judgment in proceedings intended to lead to a decision of a judicial nature. $C f$ e.g. ECJ 31 January 2013, Case C-394/11, Valeri Hariev Belov v CHEZ Elektro Balgaria AD and Others, EU:C:2013:48, para. 38; ECJ 12 June 2014, Case C-377/13, Ascendi Beiras Litoral e Alta, Auto Estradas das Beiras Litoral e Alta SA v Autoridade Tributária e Aduaneira, EU:C:2014:1754, para. 23; ECJ 6 October 2015, Case C-203/14, Consorci Sanitari del Maresme v Corporació de Salut del Maresme i la Selva, EU:C:2015:664, para. 17.

${ }^{41}$ Judgment, supra n. 1, para. 45.

42 Ibid., para. 45.

${ }^{43}$ Ibid., para. 48.

${ }^{44}$ Ibid., para. 52.

${ }^{45}$ Ibid., para. 53.
} 
Consequently, the Court concluded that the ISDS provision could not guarantee the full effectiveness of EU law in disputes concerning the interpretation or application of EU law. ${ }^{46}$

At this point, the Court found it essential to make two caveats. Firstly, it distinguished between (treaty-based) investor-State arbitration and (non-treaty based) commercial arbitration, acknowledging that, in respect of the latter, the requirements of efficient arbitration justify a limited review of arbitral awards, if the fundamental provisions of EU law can be examined in the course of that review. ${ }^{47}$ Commercial arbitration is thus not incompatible with EU law, even if the dispute in question relates to the interpretation or application of EU law and even if the arbitral tribunal is not situated within the EU judicial system, provided that fundamental provisions of EU law can be examined by national courts and referred to the Court for preliminary ruling. Secondly, the Court emphasised that the investor-State arbitration at issue was provided for in an intra-EU BIT, not in an international investment treaty concluded by the $\mathrm{EU}$, and that consequently the ruling does not extend to the latter kind of investment treaties. ${ }^{48}$ The reason for this distinction was that an ISDS provision agreed among Member States is incompatible with the principle of sincere cooperation as its calls into question the principle of mutual trust between Member States and the preservation of the particular nature of EU law ensured by the preliminary ruling procedure. ${ }^{49}$

Having thus concluded that Articles 267 and 344 TFEU precluded the ISDS provision, the Court found no need to answer the third question referred to it, namely whether the prohibition against discrimination on grounds of nationality pursuant to Article 18(1) TFEU also precluded the application of the ISDS provision.

\section{Commentary}

This commentary offers a critical analysis of the Achmea ruling, looking in turn at: (1) the extent to which an adjudicatory body may be interpreting or applying EU law for purposes of Article $344 \mathrm{TFEU}$; (2) the meaning of a court or tribunal being 'situated within the EU judicial system' for purposes of Article 267 TFEU; and (3) the extent to which EU judicial review of arbitral awards may be sufficient to safeguard the autonomy of the EU legal order. Finally, the caveats for commercial

\footnotetext{
${ }^{46}$ Ibid., para. 56.

${ }^{47}$ Judgment, supra n. 1, para. 54, citing ECJ 1 June 1999, Case C-126/97, Eco Swiss China Time Ltd v Benetton International NV, EU:C:1999:269, paras. 35, 36 and 40.

${ }^{48}$ Judgment, supra n. 1, para. 57.

${ }^{49}$ Ibid., para. 58.
} 
arbitration and ISDS provisions in international agreements concluded by the EU will be assessed.

It is important to note that the Court's ruling only concerned the EU law compatibility of the ISDS provision of the BIT at issue. The judgment did not call into question whether the substantive investment protections under the BIT, such as the fair-and-equitable-treatment provision or the free-transfer provision, were compatible with EU law. Nor was the Court called upon to examine whether the arbitral ruling was substantively in accordance with EU law, nor indeed international law.

\section{Scope of 'interpretation and application' of EU law}

From the outset, the Court did not engage with the Advocate General's view that Article 344 TFEU is limited to disputes among Member States and between Member States and the Union, ${ }^{50}$ but that it does not apply to disputes between Member States and individuals, including investor-State disputes. ${ }^{51}$ By not addressing that question, the Court appears to have endorsed the literal interpretation of Slovakia and the Commission that Article 344 TFEU is, in principle, engaged whenever a Member State submits 'a dispute concerning the interpretation or application of the Treaties to any method of settlement other than those provided for therein', i.e. regardless of the identity of the other disputant. $^{52}$

As concerns the material scope of interpretation and application of the Treaties', the Court took the view that the mere fact that an ISDS provision in an intra-EU BIT might concern disputes liable to relate to the interpretation or application of EU law, means that the provision is incompatible with the Member State's undertaking in Article 344 TFEU. The Court found it unnecessary to address the MOX Plant case and Opinion 2/13 in respect of the question whether the matters regulated by the BIT came within the scope of EU law. ${ }^{53}$ Instead the Court placed emphasis on the possibility that, even though it acknowledged that an arbitral tribunal was only called upon to rule on possible infringements of the BIT, it might also be called upon to interpret and apply EU law, and in particular

\footnotetext{
${ }^{50}$ See MOX Plant, supra n. 2, para. 128; Opinion 2/13, supra n. 2, paras. 202 and 205.

${ }^{51}$ AG's Opinion, supra n. 11, para. 146, 154.

${ }^{52}$ Ibid., para. 144.

${ }^{53}$ Ibid., paras. 160-228. In this respect, the Court also found it unnecessary to explicitly mention the fact that the reference to 'Treaties' in Art. 344 TFEU has, in its case law, been given a broad interpretation, as essentially referring to 'EU law' insofar as it concerns matters falling within EU competences. See MOX Plant, supra n. 2, para. 126 and 127; Opinion 2/13, supra n. 2, paras. 205-214.
} 
as concerns the fundamental freedoms, to determine whether a breach of the BIT had occurred. ${ }^{54}$

A less far-reaching approach was favoured by the referring court ${ }^{55}$ and the Advocate General, ${ }^{56}$ who essentially considered Article 344 TFEU only to be violated in the event that the relevant dispute in casu involved the interpretation or application of EU law and not merely was 'liable' to so relate. ${ }^{57}$ Under such an approach, investor-State arbitration under an intra-EU BIT would have been tolerated, provided that the tribunal refrained from engaging in interpretation or application of EU law. However, given that the Member State, by agreeing to the ISDS provision, had undertaken to accept the jurisdiction of the tribunal even in respect of cases relating to matters of EU law, the tribunal might have to interpret or apply EU law, even though the tribunal was stricto sensu only called upon to examine possible infringements of the terms of the BIT.

The Court's position warrant some reflection. It took a very broad view of what constitutes 'interpretation or application' of EU law. Yet, it did not analyse whether such interpretation and application by the Achmea tribunal would in any sense be binding as a matter of EU law on the Court or on national courts or tribunals. Surely the arbitral award itself remains prima facie binding on Slovakia as a matter of general international law. However, the Court did not consider the BIT to form part of EU law and therefore did not conclude that the tribunal's interpretation of the BIT was indirectly binding as a matter of EU law. ${ }^{58}$

However, could EU legal autonomy be adversely affected by interpretations of EU law that were non-binding as a matter of EU law? This might include interpretations by non-EU judicial bodies, non-judicial bodies, or indeed anyone other than EU judicial bodies, even interpretations by private parties reflected in mediated or negotiated settlements of disputes (even though such interpretations might still be binding otherwise than as a matter of EU law, such as under nonEU law).

This is a question of considerable practical consequence. It should be recalled that, whenever a national measure is internationally adjudicated and examined for

\footnotetext{
${ }^{54}$ A parallel can be found in Opinion 2/13, where the Court concluded that the 'very existence' of the possibility that EU law might be interpreted or applied in a dispute among Member States or between Member States and the Union, without recourse to the Court, 'undermines the requirement set out in Article 344 TFEU'. See Opinion 2/13, supra n. 2, para. 208.

${ }^{55}$ Judgment, supra n. 1, paras. 16-17 (in particular, para. 16: 'The dispute in the main proceedings is not such a case, however, as the arbitral award of 7 December 2012 was made on the basis of the BIT alone' [emphasis added]); $c f$ AG's Opinion, supra n. 11, para. 160.

${ }^{56}$ AG's Opinion, supra n. 11, paras. 162-173, see also paras. 174-228, in particular paras. 177-178.

${ }^{57}$ Judgment, supra n. 1, para. 39.

${ }^{58}$ CfAG’s Opinion, supra n. 11, para. 150.
} 
consistency with an international standard - such as might occur before the Appellate Body of the WTO, the International Tribunal for the Law of the Sea or the European Court of Human Rights - the meaning of that measure will necessarily have to be ascertained, which may involve interpretation of the national law that governs the measure. But this does not mean that such interpretation of national law is binding as a matter of that national law. In this respect it is pertinent to recall the famous 1925 ruling of the Permanent Court of International Justice in Certain German Interests in Polish Upper Silesia:

It might be asked whether a difficulty does not arise from the fact that the Court would have to deal with the Polish law of July 14 th, 1920 . This, however, does not appear to be the case. From the standpoint of International Law and of the Court which is its organ, municipal laws are merely facts which express the will and constitute the activities of States, in the same manner as do legal decisions or administrative measures. The Court is certainly not called upon to interpret the Polish law as such; but there is nothing to prevent the Court's giving judgment on the question whether or not, in applying that law, Poland is acting in conformity with its obligations towards Germany under the Geneva Convention. ${ }^{9}$

This equally applies when the law or other measure at issue emanates from EU law. Thus, Member States' submission to international dispute settlement could be liable to relate to the interpretation or even application of EU law in this sense. This is so regardless of whether or not the national law of the Member State or international law is explicitly designated as the law applicable to the settlement of the dispute.

Neither the Achmea ruling, nor its preceding line of cases has given a clear answer to the question whether the EU legal autonomy could be deemed adversely affected by interpretations that were not binding as a matter of EU law. ${ }^{60}$ Since the

${ }^{59}$ Certain German Interests in Polish Upper Silesia (Germany v Poland) [1926] PCIJ Rep Series A No. 7, 19 (para. 52) [emphasis added].

${ }^{60}$ Whereas the Court concluded that EU law formed part of Slovak law and derived from international agreement (Judgment, supra n. 1, para. 41) and therefore, had to be considered by the arbitral tribunal in interpreting the provisions of the BIT (ibid., para. 40), the Court did not suggest that the BIT, or the tribunal's interpretation or application of it, formed part of the EU legal order. By contrast, the AG found that it was 'clearly not the case' that the BIT would form part of EU law (AG's Opinion, supra n. 11, para. 150). Moreover, earlier case law involved interpretations or applications of EU law that would have been binding as a matter of EU law in the opinion of the Court. See Opinion 2/13, supra n. 2, paras. 180, 197 and 204, which make clear that, as a result of the EU's accession to the ECHR, the latter convention would have become binding as an integral part of EU law, and hence the ECtHR's interpretations and applications of the ECHR would have amounted to interpretations and applications of EU law; Opinion 1/09, supra n. 2, paras.79, 80 and 89, according to which the contemplated Unified Patent Court system would remove a class of disputes from Member States' jurisdiction and thus from the EU judicial system and confer exclusive jurisdiction to render binding rulings in respect of that class of disputes to the Unified Patent Court; 
Court did not even address this question, one might be inclined to conclude that it is irrelevant and that, consequently, also interpretations of EU law that are nonbinding as a matter of EU law could adversely affect the autonomy of the EU legal order. How, and for what good reason, that would be the case is not very easy to explain, however.

The converse possibility is that the distinction between binding and nonbinding interpretations of EU law by arbitral tribunals actually does matter and that the Court implicitly regarded an ancillary interpretation and application of EU law by the tribunal in the Achmea case as capable of producing binding effects within the EU legal order. This would imply that a meaningful distinction could be made between ISDS provisions depending on whether the binding interpretations of EU law might occur.

In this context, it is worth noting that the Commission in Article 8.31(2) of Canada-EU Comprehensive Economic and Trade Agreement ${ }^{61}$ has introduced a provision that makes clear that the domestic law of a contracting party (including the EU itself and its Member States) does not constitute applicable law, that such domestic law shall be regarded as a fact and that the meaning given to such domestic law by the relevant investment tribunal shall not be binding on the courts and authorities of the contracting party in question. Would such a 'carve-out' provision suffice to ensure that EU law is not being interpreted or applied in a manner that might adversely affect the autonomy of the EU legal order? Although the Court signalled that this question might indeed be answered in the affirmative, ${ }^{62}$ the question is likely to be addressed further in the Court's pending Opinion 1/17 regarding the Canada-EU Comprehensive Economic and Trade Agreement. ${ }^{63}$

MOX Plant, supra n. 2, paras. 80-82, involving interpretations and applications of provisions of the United Nations Convention on the Law of the Sea, which 'form an integral part of the Community legal order' and hence the subject matter of the relevant arbitral tribunal; Opinion 1/91, supra n. 2, para. 39, which affirmed that the EEA Court's decisions would be binding, including on the Court of Justice of the Community, insofar as the EEA Agreement was to become an integral part of the Community legal order; Opinion 1/76, supra n. 2, paras. 18-19, according to which the jurisdiction of the Fund Tribunal of the European Laying-up Fund for Inland Waterway Vessels overlapped with that of the Court of Justice of the Community.

${ }^{61}$ A similar provision has been included in other free trade agreements that have not yet been finalised, including Art. 3.23, footnote 7, to the EU-Singapore investment protection agreement (available at < trade.ec.europa.eu/doclib/docs/2018/april/tradoc_156731.pdf>, visited 27 October 2018) and Art. 15(3) and (4) of the provisional chapter on the resolution of investment disputes of the EU-Mexico free trade agreement (agreement in principle announced on 21 April 2018, available at < trade.ec.europa.eu/doclib/docs/2018/april/tradoc_156814.pdf >, visited 6 November 2018).

${ }^{62}$ Judgment, supra n. 1, paras. 57-58.

${ }^{63}$ Opinion 1/17, Canada-EU Comprehensive Economic and Trade Agreement, request submitted by the Kingdom of Belgium pursuant to Article 218(11) TFEU on 7 September 2017, OJ C 369 from 30.10.2017. 
However, paragraph 58 of the judgment holds out a third possible interpretation: that the autonomy of the EU legal order is adversely affected by 'interpretations or applications' of EU law only insofar as the principle of mutual trust is thereby called into question. Stated differently, Article 344 TFEU does not cover every interpretation or application of EU law, whether binding or nonbinding, but only those that are liable to undermine Member States' obligation 'to consider all the other Member States to be complying with EU law and particularly with the fundamental rights recognised by EU law', i.e. Member States' obligation of mutual trust. ${ }^{64}$ According to such an interpretation, the principle of legal autonomy applies only to the extent that its underlying policy justification remains valid. In this respect, paragraph 58 provides crucial information. It emphasises that an essential aspect for the outcome of the case was that the ISDS provision at issue was agreed by Member States, not by the EU itself. This, the Court explained, served to call into question 'not only the principle of mutual trust between the Member States but also the preservation of the particular nature of the law established by the Treaties, ensured by the preliminary ruling procedure provided for in Art. 267 TFEU'. As such, the ISDS provision was not compatible with the principle of sincere cooperation. The Court thus reconnected with its exposition earlier in the ruling on the structured relationship between the principles of legal autonomy and mutual trust. ${ }^{65}$

Consequently, since the Court explained that the principle of legal autonomy is ultimately derived from and justified by the principle of mutual trust, ${ }^{66}$ that justification - and the justified application of the former principle - extends no further than the latter principle is applicable. So understood, the principle of legal autonomy is thus delimited by the principle of mutual trust. With respect to such examples of international adjudication, which (normally) does not put the principle of mutual trust in jeopardy - e.g. Member States' cases before the WTO Appellate Body, the European Court of Human Rights or indeed the Canada-EU Comprehensive Economic and Trade Agreement Investment Court, the principle

\footnotetext{
${ }^{64}$ Opinion 2/13, supra n. 2, para. 191.

${ }^{65}$ Judgment, supra n. 1, paras. 32-37. It should be noted that para. 58 refers, not only to the principle of mutual trust per se, but also to the 'preservation of the particular nature' of EU law, which, as described in para. 33 of the ruling, has given rise to a structured network of principles, rules and mutually interdependent legal relations binding the EU and its Member States reciprocally and binding its Member States to each other. However, as further explained in para. 34, to which para. 58 cross-refers, EU law is thus - i.e. due to these characteristics - based on the fundamental premise of common values, which in turn implies and justifies the existence of mutual trust between the Member States. The reference to the 'particular nature' of EU law thus indirectly refers back to the principle of mutual trust. Likewise, the conclusion of para. 58, that the ISDS provision was incompatible with the principle of sincere cooperation, also refers back to the principle of mutual trust, since in para. 34, the former principle is cast as one of several emanations of the latter principle.

${ }^{66}$ Ibid., cf para. 58.
} 
of legal autonomy would, on this reading, not be adversely affected, which is exactly what the Court intimated in paragraph 57.

\section{Notion of a 'court or tribunal' situated within the EU judicial system}

The Court reaffirmed that for an adjudicatory body to be regarded as a "court or tribunal of a Member State' within the meaning of Article 267 TFEU, it must be 'situated within the EU judicial system'. On finding that the arbitral tribunal was not so situated, the Court did have not examine whether the tribunal otherwise might have satisfied - which it might have - the criteria for a 'court or tribunal' developed in case law.

What precisely is required to be situated within the EU judicial system, the Court has not exhaustively specified, either in the Achmea judgment or in prior case law. ${ }^{67}$ Nevertheless, the Court found that ISDS could not fulfil such requirements, because the raison d'être of ISDS is to set up a dispute settlement mechanism outside the judicial systems of the States that are parties to the BIT. ${ }^{68}$ The jurisdiction of arbitral tribunals under intra-EU BITs is thus 'exceptional' compared with the jurisdiction of the courts of the relevant Member States.

Nevertheless, an alternative could have been to extend the Court's control to also cover extraordinary 'courts or tribunals of a Member State', i.e. courts or tribunals that Member States may choose to set up for various purposes, but which may not be integrated with their 'ordinary' judicial systems. ISDS might be regarded as such a system.

That the Court chose not to go down that path can be explained by at least two considerations. First, it is dubious whether a failure by an investment tribunal to refer a question to the Court for a preliminary ruling could be attributable to a Member State or how otherwise the obligation to make such a reference could be enforced in respect of an adjudicatory body over which a Member State has no direct judicial oversight and control. This is indeed what the Court concluded in Opinion 1/09, where it found that 'if a decision of the [Patent Court] were to be in breach of European Union law, that decision could not be the subject of infringement proceedings nor could it give rise to any financial liability on the part of one or more Member States'. ${ }^{69}$

Second, extending the EU judicial system, and thus the right and obligation to send references for preliminary rulings, to encompass tribunals set up by Member

\footnotetext{
${ }^{67}$ The locution 'situated within the judicial system of the European Union' was used in Opinion $1 / 09$, supra n. 2, para. 82, without specifying the requirements for being so situated. However, one example that can be gleaned from the Court's reasoning is that of adjudicatory bodies deriving their authority from a Member State's national constitution, see Judgment, supra n. 1, para. 44.

${ }^{68}$ Judgment, supra n. 1, paras. 45-46.

${ }^{69}$ Opinion $1 / 09$, supra n. 2, para. 88.
} 
States outside its their own (ordinary) domestic judicial systems would imply that the rulings of such tribunals formed part of the EU legal order. Yet, the principles upon which judicial cooperation rests as between the courts subject to the Member States' judicial oversight - the principles of mutual trust and sincere cooperation - would not necessarily apply to tribunals existing outside of the Member States' judicial oversight. This reasoning appears confirmed by the Court's discussion of courts and tribunals common to several Member States. ${ }^{70}$ The example of the Benelux Court of Justice shows that such a court or tribunal, unlike investment arbitration tribunals under ISDS, remains subject to the judicial oversight of the participating Member States, while its rulings form part of the domestic legal orders of Belgium, the Netherlands and Luxembourg, i.e. have direct effect in national law.

\section{EU judicial review of arbitral awards}

Given the difficulty of integrating arbitral tribunals into the EU judicial system, one might have thought that the Court would at least have been keen to maintain judicial control at the post-award stage. However, the Court discounted the efficacy of such control essentially for two reasons.

First, it is clear that judicial review permitting references for preliminary rulings could not be ensured in all cases on the basis of the law applicable at the seat of arbitration (the lex loci arbitri). The Court observed that judicial review of arbitral awards by courts or tribunals of a Member State can only occur to the extent that national law permits. ${ }^{71}$ In the Achmea case, such review happened to be the result of the arbitral tribunal having submitted to the jurisdiction of German courts by choosing Frankfurt am Main as its seat. However, nothing would have prevented the tribunal from establishing its seat elsewhere in or outside the EU, in which case it would have been the domestic law of another Member State or a third country that governed the arbitral proceedings, subject to judicial review, if any, by the courts of that country. ${ }^{72}$

${ }^{70}$ Cf Judgment, supra n. 1, paras. 47-48.

${ }^{71}$ Cf Judgment, supra n. 1, para. 53.

${ }^{72}$ While 18 Member States have adopted legislation based on the UNCITRAL Model Law on International Commercial Arbitration (see status list available at <www.uncitral.org/uncitral/en/ uncitral_texts/arbitration/1985Model_arbitration_status.html >, visited 27 October 2018), the level of review of arbitral awards varies among them and considerably more so among the remaining Member States, with Latvia in particular having been criticised for failure to maintain a functioning system for setting aside arbitral awards, see European Parliament, Directorate-General for Internal Policies, Policy Department C (Citizens' Rights and Constitutional Affairs), Legal Affairs, Legal Instruments and Practice of Arbitration in the EU, available at < www.europarl.europa.eu/RegData/ etudes/STUD/2015/509988/IPOL_STU(2015)509988_EN.pdf> , visited 27 October 2018. 
However, the implication that the Achmea award could have entirely escaped review by Member State courts appears tenuous. The seat of arbitration is not the only relevant factor in determining the possibility for Member States courts to review arbitral awards. Even if the seat of arbitration had been outside the EU and even if the Achmea award were not set aside (which it still has not been), Slovakia could have requested Member State courts to refuse to recognise or enforce the award. While the lex loci arbitri is relevant for the purposes of setting aside (annulment) of awards, this is not necessarily the case for judicial review in the context of proceedings for the recognition and enforcement of an award.

Nevertheless, had the facts been slightly different and the arbitral proceedings had been governed by the ICSID Convention, ${ }^{73}$ by which the contracting States have undertaken to recognise and enforce arbitral awards rendered thereunder, the award would not have been subject to any further judicial review even at the stage of recognition or enforcement. ${ }^{74}$ For that very reason, such a case would probably never come before the Court. Thus, it is understandable that the Court concluded, as it did, that national law ${ }^{75}$ determines the extent of, and may thus prevent, judicial review of arbitral awards in Member States.

Second, even where judicial review takes place, the extent of that review is quite limited. Decisions to set aside or refuse to recognise or enforce an otherwise final and binding arbitral award is an exceptional measure. This state of affairs is mandated by Member States' obligations under international law. Although not mentioned by the Court in the Achmea ruling, all Member States ${ }^{76}$ are also parties to the New York Arbitration Convention, ${ }^{77}$ which limits the grounds on which a

\footnotetext{
${ }^{73}$ Convention on the Settlement of Investment Disputes between States and Nationals of Other States, signed in Washington on 18 March 1965, 575 UNTS 159 ('ICSID Convention'). All Member States, except Poland, are contracting parties to the ICSID Convention, see status list available at $<$ icsid.worldbank.org >, visited 28 October 2018. An interesting question is whether, in light of the Achmea judgment, the ICSID Convention could be regarded as a pre-accession treaty incompatible with the EU law. If indeed the ICSID Convention were so incompatible with respect to the rights and obligations of Member States vis-à-vis third countries, Art. 351 TFEU would be applicable, requiring the Member States concerned to remove such incompatibilities. However, with respect to Member States' treaty obligations inter se, Art. 351 TFEU does not apply; see ECJ 22 October 2009, Case C-301/08, Bogiatzi v Deutscher Luftpool, EU:C:2009:649, para. 19.

${ }^{74}$ Art. 54 of the ICSID Convention.

${ }^{75}$ Judgment, supra $\mathrm{n} .1$, para. 53. This would include national law implementing international commitments, such as, where applicable, the ICSID Convention.

${ }^{76}$ See UNCITRAL, status list available at <www.uncitral.org/uncitral/en/uncitral_texts/ arbitration/NYConvention_status.html >, visited 6 November 2018; cf Eco Swiss, supra n. 47, para. 38 .

${ }^{77}$ Convention on the Recognition and Enforcement of Foreign Arbitral Awards, signed in New York on 10 June 1958, 330 UNTS 38 (New York Convention).
} 
competent court may refuse to recognise or enforce an international arbitral award. ${ }^{78}$ Such a limited review could not in all cases ensure the full effectiveness and uniform application of EU law beyond the observance of its 'fundamental provisions' and perhaps not even that. ${ }^{79}$ Moreover, as already mentioned, the ICSID Convention further limits, and in fact prohibits, judicial review of arbitral awards rendered under that convention.

Given that the Achmea ruling does not contemplate an exception for situations where an arbitral award actually could be sufficiently reviewed by a Member State court, which in turn could make references for preliminary rulings under Article 267 TFEU, and since full judicial review is at odds with Member States' international commitments, few options remain for future investment arbitration under intra-EU BITs. One potential way forward to revive and retain the ability to uniformly enforce intra-EU investment protection - and perhaps the only way could be an EU-wide investment court that satisfies the requirements for being a 'court common to a number of Member States' and thus would be 'within the judicial system of the EU' for purposes of Article 267 TFEU. From the Court's earlier case law it is questionable, however, whether such a 'common investment court' could also be open to participation by third countries. ${ }^{80}$

\section{Distinguishing commercial arbitration}

The arguments relied upon by the Court to conclude that judicial review of arbitral awards is insufficient to ensure the full effectiveness and uniform interpretation

${ }^{78}$ Art. $\mathrm{V}$ of the New York Convention.

${ }^{79}$ Cf Judgment, supra n. 1, paras. 37 and 54.

${ }^{80}$ CfOpinion 1/09, supra n. 2, paras. 80-89, where the Court ruled that the contemplated patent court, which would have been established under the auspices of the European Patents Convention of 5 October 1973, to which third countries as well as Member States are parties, could not be regarded as a court common to several Member States, such as the Benelux Court of Justice, because the preliminary rulings mechanism in Art. 267 TFEU could not be effectively enforced since if a decision of the [patent court] were to be in breach of European Union law, that decision could not be the subject of infringement proceedings nor could it give rise to any financial liability on the part of one or more Member States' (para. 88). By contrast, the Court held in ECJ 4 November 1997, Case C-337/95, Parfums Christian Dior SA and Parfums Christian Dior BVv Evora BV, EU:C:1997:517, para. 30, that if a 'court like the Hoge Raad' [i.e. a national court against whose decision there is no remedy under national law] fails to make a reference for preliminary ruling pursuant to Art. 267 TFEU, a 'court like the Benelux Court' [i.e. a court common to several Member States against whose decision there is no remedy under national law] must submit such a reference. But here the Court added, very importantly: 'whose ruling may then remove from the Hoge Raad the obligation to submit a question in substantially the same terms before its judgment'. In other words, if the common court also failed to make a reference for preliminary ruling pursuant to Art. $267 \mathrm{TFEU}$, the obligation to do so would remain on the Member State's national supreme court and be the subject matter of infringement proceedings against that Member State. 
and application of EU law apply beyond the context of investment treaty arbitration between investors and States. In fact, judicial review is equally limited in scope and uncertain to occur in relation to arbitral awards rendered in the context of other types of arbitration, notably international commercial arbitration. There can be no assurances that post-award review will be possible in the context of commercial arbitration either. To the extent that judicial review does take place, the New York Convention applies equally to both investment treaty arbitration and commercial arbitration, with the same limitations on the permissible grounds for refusing recognition or enforcement.

Commercial arbitration is normally based on an arbitration agreement concluded by the disputing parties, either before or after a dispute has arisen between them. ${ }^{81}$ The parties may stipulate by mutual agreement that the disputes between them should be resolved pursuant to particular procedural rules, which the parties may find preferable to those that would otherwise apply in judicial proceedings. This includes the possibility of appointing arbitrators who enjoy the parties' trust and who have the requisite commercial competence and expertise, providing for confidentiality of proceedings, and ensuring finality, speed and efficiency. ${ }^{82}$ For these reasons, commercial arbitration is often a preferred means of dispute resolution for enterprises, accounting for a significant proportion of business disputes. ${ }^{83}$

Indeed, the Court has acknowledged the usefulness of commercial arbitration in its case law, even where it has not recognised that arbitral tribunals are 'courts or tribunals of Member States' and that disputes referred to arbitration are not subject to unlimited review by such courts or tribunals. As the Court found in the Eco Swiss case, ${ }^{84}$ the interest of efficient arbitration in the context of commercial arbitration may justify that judicial review of arbitral awards by the courts of the Member States may be limited in scope, provided that the fundamental provisions of EU law can be examined in the course of that review and, if necessary, be the subject of a reference to the Court for a preliminary ruling. This prompted the Court in the Achmea case to explain why it was not prepared to extend the same treatment to investor-State arbitration. The resulting brief explanation is the least well-argued element of the judgment. ${ }^{85}$

\footnotetext{
${ }^{81}$ See generally A. Redfern and M. Hunter et al., Law and Practice of International Commercial Arbitration, $4^{\text {th }}$ edn. (Sweet \& Maxwell 2004) p. 131-132. Commercial arbitration could involve a State, but does normally not encompass inter-State (or State-to-State) arbitration.

${ }^{82}$ See e.g. J.G. Merrills, International Dispute Settlement, $6^{\text {th }}$ edn. (Cambridge University Press 2017) p. 118-123; Redfern and Hunter, supra n. 81, p. 22-35.

${ }^{83}$ For a comprehensive empirical survey of international arbitration and settlement practice, see $\mathrm{C}$. Bühring-Uhle, L. Kirschhoff and G. Scherer, Arbitration and Mediation in International Business, $2^{\text {nd }}$ edn. (Kluwer Law International 2006) p. 105.

${ }^{84}$ Eco Swiss, supra n. 47, paras. 35, 36 and 40.

${ }^{85}$ Judgment, supra n. 1, para. 55.
} 
The Court opted to distinguish treaty-based investor-State arbitration from commercial arbitration on the basis that 'the latter originate in the freely expressed wishes of the parties, [while] the former derive from a treaty by which Member States agree to remove from the jurisdiction of their own courts, and hence from the system of judicial remedies which the second subparagraph of Article 19(1) TEU requires them to establish in the fields covered by EU law [...], disputes which may concern the application or interpretation of EU law' ${ }^{86}$

One reading of this passage seems to suggest that the Court alleged that ISDS provisions in BITs are not freely entered into by the contracting States. This misinterpretation derives from the English version of the judgment and is readily dispelled by a comparison with the German original and the French version, both of which make clear that 'the freely expressed wishes of the parties' refers to the parties to the dispute, not the parties to the arbitration agreement. This makes sense; it is a distinguishing feature of treaty-based investor-State arbitration that the disputants include an investor and a State and are thus not the same as the States that agreed to the arbitration clause in the BIT. ${ }^{87}$ There is, in other words, a lack of contractual 'privity' between the disputants.

Even so, while it is evident that treaty-based investor-State arbitration can be distinguished from commercial arbitration on the basis of the existence of privity, the legal relevance of this distinction is neither apparent nor well argued. Why should it matter for purposes of safeguarding the uniform interpretation and application of EU law whether there is privity among the disputants?

In either type of arbitration, a Member State accepts to remove disputes from the jurisdiction of its own courts. In either case, the disputes removed may concern the application or interpretation of EU law. Hence, disputes might be removed from the system of judicial remedies that the Member States are required pursuant to Article 19(1) TEU to establish in the fields covered by EU law. It should furthermore be appreciated that disputes may also be removed when States become parties to commercial arbitration and thus that ISDS may also occur in the context of commercial arbitration, notably when a State and an international investor conclude an investment contract which provides for arbitration. ${ }^{88}$

The main difference between investment-treaty arbitration and commercial arbitration is that, in the latter case, disputes are removed from the jurisdiction of courts by domestic law, which recognises the validity of arbitration agreements and allows for arbitration of certain types or classes of disputes, whereas in the case of investment treaty arbitration, the removal of disputes follows from a treaty.

\footnotetext{
${ }^{86}$ Ibid.

${ }^{87}$ See generally C. Leng Lim, J. Ho and M. Paparinskis, International Investment Law and Arbitration (Cambridge University Press 2018) p. 88-94.

${ }^{88}$ Ibid.
} 
This latter difference should be emphasised in order to properly understand the Court's reasoning. Rather than focusing on whether or not the arbitration follows from a mutual agreement between the disputants, a better way to understand the Court's reasoning is to appreciate the fact that arbitration between an investor and a Member State pursuant to an intra-EU BIT involves the removal of a dispute by mutual agreement between Member States. Thus the Court's distinction between the two kinds of arbitration focused on the prospect of Member States affecting the allocation of judicial powers enshrined in Art. 19(1) TEU by means of an inter se international agreement. ${ }^{89}$ In other words, it is not the removal of disputes, as such, that is very problematic, so much as the fact that the two Member States in question have 'contracted out' of their obligation of mutual trust vis-à-vis each other ('to consider all the other Member States to be complying with EU law and particularly with the fundamental rights recognised by EU law') by agreeing on treaty-based ISDS.

Perhaps the concern is broader, extending to international agreements with third countries, e.g. ISDS under a BIT between a Member State and a third country. But, as discussed above, ${ }^{90}$ such an interpretation of the notion of legal autonomy would not be justified on the basis of the principle of mutual trust, which does not extend to third countries.

\section{Distinguishing international agreements concluded by the $E U$}

By emphasising that the ISDS provision at issue had been agreed in an international treaty, not concluded by the EU, but by Member States, the Court clarified its concern that Member States might use ISDS provisions in intra-EU BITs to contract out of, or otherwise circumvent, their obligations under the Treaties. ${ }^{91}$ On the premise of their shared fundamental values, the Netherlands and Slovakia were obliged to mutually trust the functioning of each other's judicial systems and not rely on international arbitration outside those systems to settle investment disputes arising out of the BIT. Intra-EU ISDS is a sign of distrust; by allowing Member States to go beyond their domestic systems of judicial remedies would appear to obviate the need for mutual trust and hence also the necessity of ensuring the continued validity of the premise of shared fundamental values. The existing intra-EU ISDS practice thus has the propensity of relaxing that premise, the consequences of which is both unforeseeable and of potentially existential importance for the future of the EU.

\footnotetext{
${ }^{89}$ Cf Judgment, supra n. 1, para. 55.

${ }^{90}$ Cf discussion at supra nn. 64-66.

${ }^{91}$ Cf Judgment, supra n. 1, paras. 57-58.
} 
The same concern does not present itself in the context of international arbitration agreed by the EU itself. Surely, such an agreement could also adversely affect the allocation of powers fixed by the Treaties and thus the autonomy of the EU legal order. However, the reason for not accepting the same limited judicial review of arbitral awards with respect to investment treaty arbitration as in the context of commercial arbitration - i.e. the risk of a re-allocation of judicial powers enshrined in Art. 19(1) TEU by means of an inter se international agreement - is not similarly present where it is the EU itself that submits to the arbitration. Again, the difference is the obligation of mutual trust, which is owed by and between the Member States, not by the EU itself, and is therefore not undermined when it is the EU that acts.

\section{CONCLUding ReMARKS}

The generality of the Achmea ruling implies a need to re-evaluate the EU law compatibility of current dispute settlement mechanisms that are liable to relate to the interpretation or application of EU law. Potentially any dispute settlement system outside the judicial systems of the Member States and outside the Treaties, to which a Member State may submit, might involve the interpretation or application of EU law. Unless such system is subject to full judicial review by the Member State's courts or tribunals, the autonomy of the EU legal order might be adversely affected. Apart from commercial arbitration, this appears to leave no room for ISDS under any BITs, including BITs with third countries, nor for State-State dispute settlement involving third countries, such as the WTO dispute settlement system, and even potentially Member States' (own) submission to international dispute settlement, such as to the jurisdiction of the European Court of Human Rights.

This case note has suggested a less radical reading of Achmea, namely that not all interpretations or applications of EU law come under Article 344 TFEU and are liable to adversely affect the autonomy of the EU legal order, but only those that undermine the principle of mutual trust, which is owed by and between Member States, but not by the EU nor by the Member States towards third countries. Such a reading would leave outside the ambit of Article 344 TFEU any dispute settlement systems agreed with third countries. It would also explain why commercial arbitration, which is not conducted on the basis of an agreement between Member States, is unproblematic from the perspective of EU legal autonomy, even though it removes classes of disputes from the system of judicial remedies that the Member States are required pursuant to Article 19(1) TEU to establish in the fields covered by EU law.

In any event, the immediate legal consequences of the Achmea ruling are far from straightforward. Arbitral tribunals have so far rejected jurisdictional 
objections of Member States and the Commission based on Article 344 TFEU, ${ }^{92}$ but - being obliged to render enforceable rulings - will now have to reconsider their stance. ${ }^{93}$ Courts of the Member States reviewing arbitral awards in intra-EU investment treaty arbitrations will have to grapple with the consequences of potentially being unable to accommodate the Achmea ruling without disregarding Member States' national legislative and constitutional limitations on arbitral annulment or their international commitments, such as the New York Convention or the ICSID Convention. Although the principle of primacy of EU law ought to dispose of these issues, the Court in Eco Swiss chose to defer to Member States' procedural requirements for annulment of an arbitral award for failure to observe national rules of public policy. ${ }^{94}$ The Court in Achmea distanced itself from Eco Swiss in respect of intra-EU treaty-based ISDS, but does this mean that Member States are now subject to a new requirement to annul arbitral awards for failure to observe EU public policy? It would not be surprising if further references for preliminary rulings addressed these points.

What about intra-EU treaty-based investment arbitration where the seat of arbitration has been established in a third country? Member State courts seised with an application to refuse the recognition or enforcement of an arbitral award

\footnotetext{
${ }^{92}$ See cases cited in supra $\mathrm{n} 10$.
}

${ }^{93}$ The Achmea judgment has already been invoked by Member State respondents in a number of pending investment arbitration cases, giving rise to jurisdictional objections, see e.g. ICSID Case No. ARB/15/31, Respondent's Additional Preliminary Objection dated 25 May 2018, Gabriel Resources Ltd and Gabriel Resources (Jersey) Ltd $\mathrm{v}$ Romania, paras. 97-117, as well as applications to reopen the arbitral procedure based on the Achmea judgment, which have so far been denied, see e.g. Masdar Solar \& Wind v Spain, supra n. 10, paras. 678-683; PCA Case No. 2014-01, Award dated 2 May 2018, Antaris GmbH and Dr Michael Göde v Czech Republic, para. 73; ICSID Case No. ARB/13/31, Award dated 15 June 2018, Antin Infrastructure Services Luxembourg S.à r.l and Antin Energia Termosolar BV v Kingdom of Spain, paras. 56-58. With respect to the arbitral award in SCC Case V 2015/063, Final Arbitral Award dated 15 February 2018, Novenergia II - Energy \& Environment (SCA) (Grand Duchy of Luxembourg), SICAR $\mathrm{v}$ Kingdom of Spain, the respondent has applied to have the award set aside and to stay any potential enforcement of the award while the setting-aside application is pending, see Svea Court of Appeal Case No. T-4658-18, Decision dated 17 May 2018, Konungariket Spanien (Kingdom of Spain) v Novenergia II - Energy \& Environment (SCA), SICAR.

${ }^{94}$ Eco Swiss, supra n. 47, paras. 37-41, where the Court ruled that, if a national court considered an arbitral award to be contrary to EU law, that court must allow a claim for annulment of the award on the basis of the award being contrary to public policy, 'where [the national court's] domestic rules of procedure require it to grant an application for annulment founded on a failure to observe national rules of public policy' (para. 41). Thus, the Court answered in the negative the referring court's question (para. 30): '[i]f the court considers that an arbitration award is in fact contrary to Article 85 of the EC Treaty, must it, on that ground and notwithstanding the rules of Netherlands procedural law [...] [according to which a party may claim annulment of an arbitration award only on a limited number of grounds, one ground being that an award is contrary to public policy] [...], allow a claim for annulment of that award if the claim otherwise complies with statutory requirements?' [emphasis added]. 
rendered in an intra-EU investment treaty arbitration will also have to consider the limitations provided under Article V of the New York Convention. Specifically, Member State courts will have to assess whether the Achmea ruling should be interpreted as a case of 'objective non-arbitrability', ${ }^{95}$ even though it is not so much the subject matter of the dispute per se that is incapable of settlement by arbitration, as it is the capacity of one of the disputants to validly submit to arbitration that is called into question, i.e. subjective arbitrability? ${ }^{96}$ But in the latter case, could a Member State validly invoke its own incapacity pursuant to Article 46 of the Vienna Convention on the Law of Treaties by arguing that the lack of capacity was manifest, and did that incapacity exist at the time that the arbitration agreement was concluded? Or should the ISDS clauses in intra-EU BITs be regarded as having been overridden pursuant to Article 59 of the Vienna Convention on the Law of Treaties or modified pursuant to Article 30(3) or (4) of the same Treaty by accession to, or successive amendments of, the Treaties?

With respect to the future of investment treaty arbitration, the Achmea ruling may finally spur Member States to terminate their intra-EU BITs, even though most such BITs provide for 'sunset clauses' - an extended period of applicability following termination - and modify inter se the ISDS provisions of the Energy Charter Treaty. The ruling may also incentivise investors to structure future investments so as to benefit from the ICSID Convention, avoid reliance on investment protections under intra-EU BITs, or, where possible, seek to enforce awards against assets held outside the EU. With respect to non-ICSID cases, arbitrators may choose to establish seats of arbitration outside the EU. More generally, investors may gradually turn away from relying on investment treaties in favour of concluding investment contracts or investment guarantees directly with Member States and agree in such context to settle disputes by means of commercial arbitration, which will likely not be an option for investors in all economic sectors, for small- or medium-sized investors or for investors lacking political access.

\footnotetext{
${ }^{95}$ Art. V(2)(a) of the New York Convention.

${ }^{96}$ Art. V(1)(a), first prong, of the New York Convention. In Gabriel Resources v Romania, supra $\mathrm{n}$. 93, the respondent has argued, following the Achmea judgment, that the claimant lost the right to lawfully consent to arbitration 'at the latest when the TFEU came into force' (para. 103) and that also the respondent's own consent also become inapplicable at that time (para. 103). See further paras. 104-117.
} 